\title{
Serum levels of adiponectin, CCL3/MIP-1 $\alpha$, and CCL5/RANTES discriminate migraine from tension-type headache patients
}

Níveis séricos de adiponectina, CCL3/MIP-1 $\alpha$ e CCL5/RANTES discriminam pacientes com migrânea e cefaleia do tipo tensional

Renan B. Domingues ${ }^{1,2}$, Halina Duarte1, Carlos Senne ${ }^{2,3}$, Gustavo Bruniera ${ }^{2,3}$, Fernando Brunale ${ }^{2,3}$, Natália P. Rocha ${ }^{4}$, Antonio L. Teixeira ${ }^{1,4}$

\begin{abstract}
Objectives: Inflammatory molecules and neurotrophic factors are implicated in pain modulation; however, their role in primary headaches is not yet clear. The aim of this study was to compare the levels of serum biomarkers in migraine and tension-type headache. Methods: This was a cross-sectional study. We measured serum levels of adiponectin, chemokines, and neurotrophic factors in patients with migraine and tension-type headache. Depression and anxiety symptoms, headache impact and frequency, and allodynia were recorded. Results: We included sixty-eight patients with migraine and forty-eight with tension-type headache. Cutaneous allodynia ( $p=0.035)$, CCL3/MIP-1 $\alpha$ $(p=0.041)$, CCL5/RANTES ( $p=0.013)$, and ADP ( $p=0.017)$ were significantly higher in migraine than in tension-type headache. The differences occurred independently of anxiety and depressive symptoms, frequency and impact of headache, and the presence of pain. Conclusions: This study showed higher CCL3/MIP-1 $\alpha$, CCL5/RANTES, and ADP levels in migraine in comparison with tension-type headache. Our findings suggest distinctive roles of these molecules in the pathophysiology of these primary headaches.
\end{abstract}

Keywords: migraine disorders; tension-type headache; adiponectin; chemokines; neurotrophic factors.

\section{RESUMO}

Objetivos: Moléculas inflamatórias e fatores neurotróficos estão implicados na modulação dolorosa, contudo, seu papel nas cefaleias primárias não é claro. O objetivo do presente estudo foi comparar níveis de biomarcadores séricos na migrânea e cefaleia do tipo tensional. Métodos: Este foi um estudo transversal, no qual foram avaliados níveis de adiponectina, quimiocinas e fatores neurotróficos em pacientes com migrânea e cefaleia do tipo tensional. Sintomas depressivos e ansiosos, o impacto e a frequência da cefaleia e alodínea foram registrados. Resultados: Foram incluídos 68 pacientes com migrânea e 48 pacientes com cefaleia do tipo tensional. A alodínia cutânea ( $p=0.035)$, CCL3/MIP-1 $\alpha$ $(p=0.041)$, CCL5/RANTES ( $p=0.013$ ), e adiponectina ( $p=0.017)$ foram maiores na migrânea, independentemente de sintomas depressivos e ansiosos, frequência e impacto da cefaleia. Conclusões: Niveis de CCL3/MIP-1 $\alpha$, CCL5/RANTES e adiponectina foram maiores na migrânea do que na cefaleia do tipo tensional, sugerindo papeis distintos destas moléculas na fisiopatologia destas duas cefaleias primárias.

Palavras-chave: transtornos de enxaqueca; cefaleia do tipo tensional; adiponectina; quimiocinas; fatores neurotróficos.

Migraine and tension-type headache (TTH) are the most frequent primary headaches and their differentiation is based on strict clinical diagnostic criteria ${ }^{1}$. Though different theories have been formulated to explain these disorders, their physiopathology remains largely unknown.

Migraine is considered a neurovascular disorder with complex genetic background. Trigeminovascular system activation with subsequent release of vasoactive neuropeptides has been proposed to explain migraine attacks ${ }^{2}$, while central sensitization possibly plays a role in migraine chronification ${ }^{3}$. Conversely, TTH pathophysiology has been thought to be associated with both peripheral (increased myofascial pain sensitivity and peripheral sensitization of myofascial nociceptors) and central

\footnotetext{
${ }^{1}$ Universidade Federal de Minas Gerais, Programa de Neurociências, Belo Horizonte MG, Brasil;

${ }^{2}$ Senne Liquor Diagnóstico, São Paulo SP, Brasil;

${ }^{3}$ Universidade Federal de Minas Gerais, Faculdade de Medicina, Laboratório Interdisciplinar de Investigação Médica, Belo Horizonte MG, Brasil;

${ }^{4}$ Hospital Israelita Albert Einstein, Laboratório de Patologia Clínica, São Paulo SP, Brasil.
}

Correspondence: Renan B. Domingues; Rua Almeida Torres, 119/133A ; 01530-010 São Paulo SP, Brasil; E-mail: contato@renandomingues.med.br Conflict of interest: There is no conflict of interest to declare.

Support:This work was funded by CNPq and Fapemig, Brazil.

Received 16 September 2015 ; Accepted 25 May 2016. 
(sensitization of second-order neurons and somatosensory cortex) mechanisms ${ }^{4}$.

Adiponectin (ADP) is a cytokine exclusively secreted by adipocytes that participates in the regulation of glucose and lipids metabolism, and also displays anti-inflammatory properties. Its plasmatic levels are reduced in obesity, insulin resistance, and metabolic syndrome; while its levels were shown to be raised in inflammatory diseases such as rheumatoid arthritis and inflammatory bowel disease $^{5}$. Chemokines (i.e. chemoattractant cytokine) are a family of small proteins that mediate the migration of leukocytes into inflammatory sites. The family is composed of about 50 related molecules divided into four subfamilies according to the number and spacing of cysteine residues $^{6}$. Neurotrophic factors are polypeptides responsible for neuron survival, axon growth, and the expression of essential proteins for neuronal functioning. Neurotrophic factors are classified in different families, such as the glial cell line-derived neurotrophic factor (GNDF) family and the neurotrophin super-family that includes the brain-derived neurotrophic factor (BDNF), the nervegrouwth factor (NGF), the neurotrophin-3 (NT-3), and the neurotrophin-4/5 (NT-4/5)

Some studies have proposed that pro- and anti-inflammatory molecules may play a role in the pathophysiology of migraine $^{8,9,10}$ and $\mathrm{TTH}^{11,12,13}$. The association between neurotrophic factors and migraine $\mathrm{e}^{14,15,16}$, and neurotrophic factors and $\mathrm{TTH}^{17,18}$ has also been investigated. As different pathophysiological mechanisms have been proposed for migraine and TTH, it is possible that the profile of these molecules may be distinct in these two disorders. No previous study has compared these molecules levels in patients with migraine and TTH.

The aim of the current study was to compare ADP, chemokines, and neurotrophic factors serum levels between migraine and TTH patients.

\section{METHOD}

We have recently compared $\mathrm{ADP}$, chemokines, and neurotrophic factors between patients with migraine and controls $^{9,10,14,16}$, and between patients with TTH and controls ${ }^{12,13,18}$. In the current study we aimed to compare these molecules levels between a group of patients with migraine and a group of patients with TTH.

This was a cross section study including sixty-eight patients with migraine and forty-eight patients with TTH prospectively enrolled from the headache outpatient clinic of the Santa Casa de Misericórdia Hospital, Vitória, Brazil at their first visit to the clinic. All diagnoses were in accordance with the International Classification on Headache Disorders $-2^{\text {nd }}$ edition ${ }^{19}$. The minimal age for the inclusion of patients was 18 years-old. Patients with inflammatory, infectious, autoimmune, and neoplasic diseases were not included in the study, as well as pregnant women and people in use of corticosteroids or immunosuppressant drugs. Demographic (age, ethnicity, and marital status) and headache (time of disease, frequency of attacks in the last month) data were recorded. The Beck Anxiety Inventory (BAI) was used to evaluate the severity of anxiety symptoms, while the Beck Depression Inventory (BDI) the severity of depressive symptoms. Body mass index (BMI), Headache impact test (HIT-6) ${ }^{20}$ and allodynia symptom checklist (ASC), with cutaneous allodynia defined as ASC score $\geq 3^{21}$, were recorded from all subjects. This study received full approval by the Ethics Committee on Research of the "Escola Superior de Ciências da Santa Casa de Vitória”, Vitória, Brazil, and informed consent was obtained from each patient.

Whole blood was collected from all the participants, and serum was obtained after centrifugation and kept at $-80 \mathrm{C}$ until analysis. For analysis we used the same procedures previously described ${ }^{9,10,12,13,14,16,18}$. The assay conditions were controlled, standardized and pre-optimized to ensure repeatability and reproducibility. Analyses were blinded to clinical diagnosis.

\section{Statistical analysis}

The data were analyzed with the SPSS, version 15.0 for Windows. The confidence interval was of $95 \%$ and the significance level was set at $\mathrm{P}<0.05$. Verification of normal distribution of data was performed using the Kolmogorov-Smirnov test. Mann-Whitney was used for the medians comparisons of continuous data. Categorical characteristics were compared using chi-square analyses. Binary logistic regression analysis with elimination of nonsignificant covariates was performed with the diagnosis of migraine and TTH as the dependent variables.

\section{RESULTS}

Migraine and TTH patients did not differ in age, sex, ethnicity, BMI, marital status, time of disease, and age at headache onset (Table 1). Migraine patients showed more depressive and anxiety symptoms than TTH patients as assessed by BDI and BAI, respectively (Table 1). Patients with migraine had higher number of headache days per month, percentage of chronic headache (> 15 headache days per month), headache impact, and percentage of cutaneous allodynia (Table 1). The percentages of migraine and TTH patients with headache at the time of the assessment were not significantly different.

In univariate analysis, a significant difference in CCL11 (chemokineligand 11)/eotaxin( $\mathrm{P}=0.043)$, CCL24(chemokine ligand 24)/Eotaxin2 ( $\mathrm{p}=0.003$ ), CXCL10/IP-10 (chemokine ligand 10/interferon gamma inducible protein-10) ( $\mathrm{p}<0.001$ ), CCL2/MCP-1 (chemokine ligand 2/ monocyte 
chemoattractant protein-1) $(\mathrm{p}=0.034)$ CCL3/MIP-1 $\alpha$ (chemokine ligand 3/ macrophage inflammatory protein-1 alpha) ( $p=0.001$ ), CCL5/RANTES (chemokine ligand $5 /$ regulated on activation, normal $\mathrm{T}$ cell expressed and secreted) $(p=0.002)$, and $\operatorname{ADP}(p<0.001)$ serum levels were found between migraine and TTH (Table 2). No significant differences were found in neurotrophic factors levels between migraine and TTH. After adjusted analysis including ASC score, depression and anxiety scores, ADP, chemokines, and neurotropic factors levels as covariates and migraine and TTH as dependent variables we found that the only variables independently associated with the diagnosis (headache $\mathrm{x}$ TTH) were cutaneous allodynia $(P=0.035)$, CCL3/MIP $1 \alpha(p=0.041)$, CCL5/RANTES $(\mathrm{p}=0.013)$, and $\operatorname{ADP}(\mathrm{p}=0.017)$ (Figure).

\section{DISCUSSION}

The current study showed that higher serum levels of CCL3/MIP-1 $\alpha$, CCL5/RANTES, and ADP discriminate migraine patients from TTH patients.

Table 1. Demographic and clinical characteristics in patients with migraine and tension-type headache.

\begin{tabular}{|c|c|c|c|}
\hline Variable & Migraine & Tension-Type Headache & $p$ \\
\hline Age (years) & $44(18-64)$ & $43.5(19-76)$ & 0.730 \\
\hline \multicolumn{4}{|l|}{ Gender } \\
\hline Male (\%) & $5(4.3)$ & $5(4.3)$ & \\
\hline Female (\%) & $63(54.3)$ & $43(37.1)$ & 0.563 \\
\hline \multicolumn{4}{|l|}{ Marital status } \\
\hline Married (\%) & $34(29.3)$ & $15(12.9)$ & \\
\hline Single (\%) & $34(29.3)$ & $33(28.5)$ & 0.440 \\
\hline \multicolumn{4}{|l|}{ Ethnic distribution } \\
\hline White & $32(27.6)$ & $20(17.2)$ & \\
\hline Brown & $30(25.9)$ & $23(19.8)$ & 0.841 \\
\hline Black & $6(5.2)$ & $5(4.3)$ & \\
\hline BMI: body mass index & $25.07(19.4-32)$ & $25.6(18.75-45.72)$ & 0.518 \\
\hline Time of disease (years) & $20(3-45)$ & $13(1-51)$ & 0.055 \\
\hline Age of onset (years) & $16(7-58)$ & $17(7-58)$ & 0.780 \\
\hline BDI: beck depression inventory & $11(0-41)$ & $8(0-54)$ & $0.010^{*}$ \\
\hline BAl: beck anxiety inventory & $9(1-54)$ & $7.5(0-22)$ & $0.022^{\star}$ \\
\hline HIT-6: headache impact test & $63(36-76)$ & $51.5(36-70)$ & $<0.001 *$ \\
\hline Number of headache days per moth & $7(1-15)$ & $3(1-30)$ & $<0.001^{\star}$ \\
\hline Chronic headache (\%) & $23(33.8)$ & $5(10.4)$ & $0.004 * \star$ \\
\hline Headache at the time of clinical assessment (\%) & $19(27.9)$ & $14(29.2)$ & 0.885 \\
\hline Cutaneous allodynia (\%) & $36(52.9)$ & $7(14.6)$ & $<0.001 * \star$ \\
\hline
\end{tabular}

* Mann-Whitney test; ${ }^{* *}$ Chi-square analyses.

Table 2. Adiponectin, chemokines, amd neurotrophic factors levels in patients with migraine and tension-type headache.

\begin{tabular}{lccc}
\hline Variable & Migraine & Tension-Type Headache & $p$ \\
\hline CCL11/eotaxin $(\mathrm{pg} / \mathrm{mL})$ & $777.7(300.5-11663.3)$ & $819.05(163.84-12460)$ & $0.043^{*}$ \\
CCL24/Eotaxin2 $(\mathrm{pg} / \mathrm{mL})$ & $2507.7(461.2-8192.5)$ & $2340.7(501.6-8360.5)$ & $0.003^{*}$ \\
CXCL8//L-8 $(\mathrm{pg} / \mathrm{mL})$ & $457.7(276.25-653.7)$ & $412.78(123.4-1756.3)$ & 0.660 \\
CXCL10/IP-10 $(\mathrm{pg} / \mathrm{mL})$ & $295.7(198-2180.2)$ & $2674(133-5037.6)$ & $<0.001^{*}$ \\
CCL2/MCP-1 $(\mathrm{pg} / \mathrm{mL})$ & $2479.1(976.1-8202.2)$ & $1812.4(669.3-31056.8)$ & $0.034^{*}$ \\
CCL3/MIP-1 $\alpha(\mathrm{pg} / \mathrm{mL})$ & $341.8(13.5-15719.4)$ & $183.1(13.5-15592.8)$ & $0.001^{*}$ \\
CCL5/RANTES $(\mathrm{pg} / \mathrm{mL})$ & $21643.4(1765.1-28790.7)$ & $20052.4(0-40027.6)$ & $0.002^{*}$ \\
GNDF $(\mathrm{pg} / \mathrm{mL})$ & $68.2(6.5-4730.9)$ & $80.4(5.1-7311.8)$ & 0.850 \\
NGF $(\mathrm{pg} / \mathrm{mL})$ & $64.4(15.8-217.2)$ & $77.82(0-4737.4)$ & 0.730 \\
NT-3 $(\mathrm{pg} / \mathrm{mL})$ & $45.7(8.4-4835.3)$ & $32.3(7.9-6141.6)$ & 0.346 \\
NT-4/5 $(\mathrm{pg} / \mathrm{mL})$ & $34.7(15.3-3078.5)$ & $6532.9(4083.4-11584.6)$ & 0.187 \\
BDNF $(\mathrm{pg} / \mathrm{mL})$ & $6476.9(3854.5-9305.9)$ & $31150(20421.2-69227.6)$ & 0.850 \\
Adiponectin $(\mathrm{pg} / \mathrm{mL})$ & $42075.9(24915.3-48045.9)$ & $0.001^{*}$ \\
\hline
\end{tabular}

CCL2/MCP-1: chemokine ligand 2/ monocyte chemoattractant protein-1;CCL3/MIP-1 $\alpha$ : chemokine ligand 3/macrophage inflammatory protein-1 alpha; CCL5/ RANTES: chemokine ligand 5/regulated on activation, normal T cell expressed and secreted; CXCL8/IL-8: chemokine ligand 8/interleukin-8; CXCL10/IP-10: chemokine ligand 10/interferon gamma inducible protein-10; GDNF: Glial cell line-derived neurotrophic factor; NGF: Nerve-growth factor; NT: neurotrophin-3 and neurotrophin-4/5.

*Mann-Whitney test. 
Allodynia

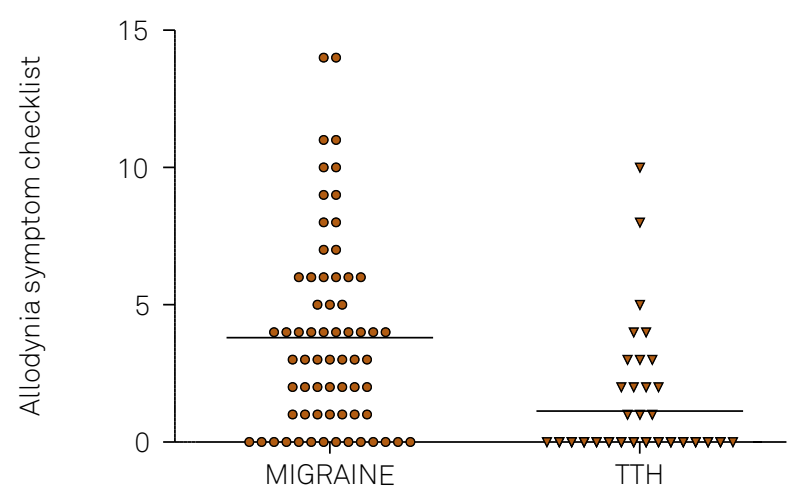

CCL5/RANTES

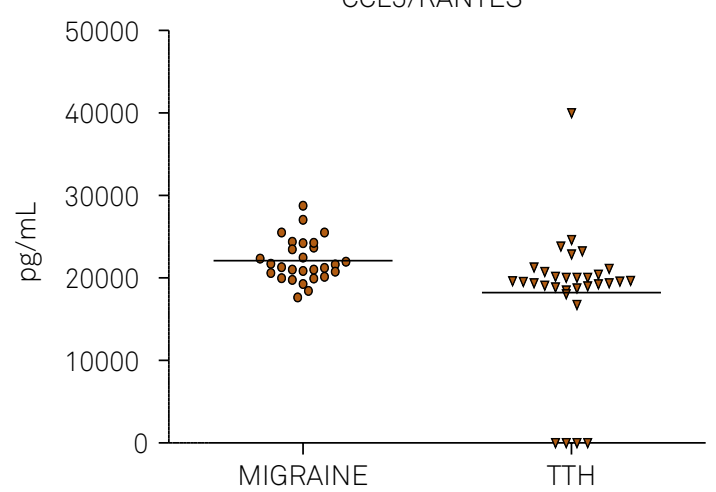

CCL3/MIP $1 \alpha$

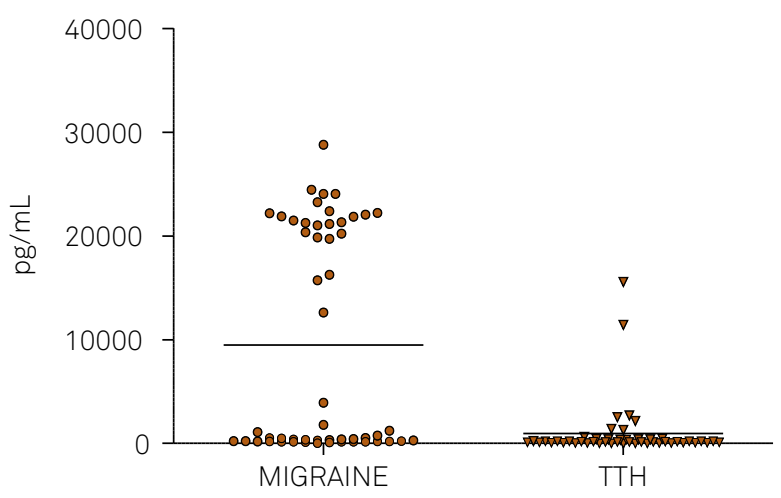

ADP

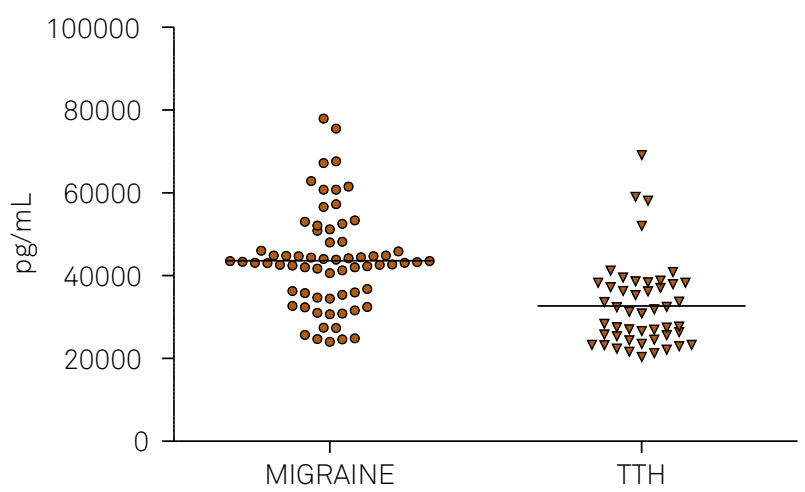

Figure. Allodynia, CCL3/MIP-1 $\alpha$ (chemokine ligand 3/ macrophage inflammatory protein-1 alpha), CCL5/RANTES (chemokine ligand $5 /$ regulated on activation, normal T cell expressed and secreted), and adiponectin in migraine and tension-type headache patients. Differences in allodynia symptom checklist (A) and in plasma levels of CCL3/MIP-1 $\alpha$ (B), CCL5/RANTES (C), and adiponectin (D) between patients with migraine and tension-type headache (TTH).

CCL-3/MIP-1 $\alpha$ is a pro-inflammatory chemokine that participates in acute and chronic inflammatory responses by recruiting T-cells, monocytes, dendritic, and NK cells, playing an important role in the pathogenesis of many inflammatory conditions $^{22}$. CCL-3/MIP- $1 \alpha$ also acts as a mediator of chronic pain ${ }^{23}$. We have previously shown that CCL-3/MIP-1 $\alpha$ levels were higher in migraine patients than in subjects without any type of headache disorder ${ }^{10}$, but CCL-3/MIP-1 $\alpha$ levels in migraine have not been compared with other headache disorders yet.

CCL5/RANTES is a protein that is chemotactic for T-cells and eosinophils, among other leukocytes ${ }^{24}$. This molecule is also involved in sensory regulation and neuropathic pain ${ }^{23}$. CCL5/RANTES has been previously shown to be higher during migraine attacks ${ }^{25}$, but in the present study this molecule was higher in migraine regardless of presence of pain.

The higher ADP levels in migraine found in the present study are in agreement with some previous studies ${ }^{9,10}$, although discrepant findings have also been reported ${ }^{26}$.

The fact that these three molecules were increased in migraine compared with TTH strengthens the hypothesis that inflammatory mechanisms are involved in the pathophysiology of migraine. This finding also supports that different pathophysiological processes underlie these two disorders. It is tempting to speculate that inflammatory molecules may exert a stimulatory effect on the trigeminal vascular system thus enhancing the susceptibility to migraine attacks ${ }^{27}$. Alternatively, these molecules played a role in sensory regulation and sensitization. Our findings are compatible with the latter hypothesis since migraine patients had significantly more cutaneous allodynia, a marker of central sensitization, than patients with $\mathrm{TTH}^{26}$. It is possible that the increased production of these molecules affects sensory regulation promoting central sensitization that occurs to a greater extent in migraine than in TTH.

Patients with anxiety and depressive symptoms have higher levels of chemokines ${ }^{28,29}$ and $\mathrm{ADP}^{30}$. Considering that migraine patients had more depressive and anxiety symptoms than patients with TTH, this could potentially explain the observed elevated levels of CCL-3/MIP-1, CCL5/RANTES, and ADP in migraine. Nevertheless this hypothesis seems 
unlikely since the results persisted after adjusted analysis with anxiety and depression scores as covariates, suggesting that the higher levels of CCL-3/MIP-1, CCL5/RANTES, and $\mathrm{ADP}$ in migraine were not due to the presence of psychiatric comorbidities. It is also unlikely that the found difference was the result of increased frequency and impact of headache in patients with migraine in comparison with TTH.

The limitations of the present study include its crosssectional design, precluding the establishment of causal relationships. Also, we found only a modest difference between $\mathrm{ADP}$ and chemokine levels between migraine and TTH with a considerable overlap between these two populations. This undermines the potential role of these molecules as biomarkers of migraine diagnosis. Therefore, larger and prospective studies are still needed to investigate their role as biomarkers. As strengthens of the study it must be mentioned the number of subjects enrolled and the several serum biomarkers measured.

In conclusion, our results suggest that the inflammatory process is involved in the pathophysiology of migraine. The different profile of inflammatory markers can contribute to a better understanding of the pathophysiological boundaries between migraine and TTH. A better knowledge on the molecules involved in primary headache pathogenesis may tailor the development of new and more effective pharmacological strategies for the treatment of these disorders.

\section{Aknowledgments}

We greatflully aknowledge the contribution of Cassio Lacerda and Tarnara Campostrini in data collection.

\section{References}

1. Silva Junior AA, Bigal M, Vasconcelos LP, Rodrigues J, Gomez RS, Krymchantowski AV et al. Prevalence and burden of headaches as assessed by the health family program. Headache. 2012;52(3):483-90. doi:10.1111/j.1526-4610.2012.02090.x

2. Goadsby PJ, Edvinsson L, Ekman R. Vasoactive peptide release in the extracerebral circulation of humans during migraine headache. Ann Neurol. 1990;28(2):183-7. doi:10.1002/ana.410280213

3. Welch KM, Nagesh V, Aurora SK, Gelman N. Periaqueductal gray matter dysfunction in migraine: cause or the burden of illness? Headache. 2001;41(7):629-37. doi:10.1046/j.1526-4610.2001.041007629.x

4. Bendtsen L, Jensen R. Tension-type headache. Neurol Clin. 2009;27(2):525-35. doi:10.1016/j.ncl.2008.11.010

5. Fantuzzi G. Adiponectin and inflammation: consensus and controversy. J Allergy Clin Immunol. 2008;121(2):326-30. doi:10.1016/j.jaci.2007.10.018

6. Charo IF, Ransohoff RM. The many roles of chemokines and chemokine receptors in inflammation. N Engl J Med. 2006;354(6):610-21. doi:10.1056/NEJMra052723

7. Allen SJ, Dawbarn D. Clinical relevance of the neurotrophins and their receptors. Clin Sci (Lond). 2006;110(2):175-91. doi:10.1042/CS20050161

8. Peterlin BL, Bigal ME, Tepper SJ, Urakaze M, Sheftell FD, Rapoport AM. Migraine and adiponectin: is there a connection? Cephalalgia. 2007;27(5):435-46. doi:10.1111/j.1468-2982.2007.01306.x

9. Duarte H, Teixeira AL, Rocha NP, Domingues RB. Increased serum levels of adiponectin in migraine. J Neurol Sci. 2014;342(1-2):186-8. doi:10.1016/j.jns.2014.04.035

10. Duarte H, Teixeira AL, Rocha NP, Domingues RB. Increased interictal serum levels of CXCL8/IL-8 and CCL3/MIP-1 $\alpha$ in migraine. Neurol Sci. 2014;36(2):203-8. doi:10.1007/s10072-014-1931-1

11. Koçer A, Koçer E, Memișoğullari R, Domaç FM, Yüksel H. Interleukin-6 levels in tension headache patients. Clin J Pain. 2010;26(8):690-3. doi:10.1097/AJP.0b013e3181e8d9b6

12. Domingues RB, Duarte H, Rocha NP, Teixeira AL. Reduced serum levels of adiponectin in tension-type headache. Clin Neurol Neurosurg. 2015;131:82-5. doi:10.1016/j.clineuro.2015.01.026
13. Domingues RB, Duarte H, Rocha NP, Teixeira AL. Increased serum levels of interleukin-8 in patients with tension-type headache. Cephalalgia. 2015;35(9):801-6. doi:10.1177/0333102414559734

14. Tanure MT, Gomez RS, Hurtado RC, Teixeira AL, Domingues RB. Increased serum levels of brain-derived neurotropic factor during migraine attacks: a pilot study. J Headache Pain. 2010;11(5):427-30. doi:10.1007/s10194-010-0233-0

15. Sarchielli P, Mancini ML, Floridi A, Coppola F, Rossi C, Nardi K et al. Increased levels of neurotrophins are not specific for chronic migraine: evidence from primary fibromyalgia syndrome. J Pain. 2007;8(9):737-45. doi:10.1016/j.jpain.2007.05.002

16. Martins LB, Duarte H, Ferreira AV, Rocha NP, Teixeira AL, Domingues RB. Migraine is associated with altered levels of neurotrophins. Neurosci Lett. 2015;587:6-10. doi:10.1016/j.neulet.2014.12.022

17. Fischer M, Wille G, Klien S, Shanib H, Holle D, Gaul C et al. Brainderived neurotrophic factor in primary headaches. J Headache Pain. 2012;13(6):469-75. doi:10.1007/s10194-012-0454-5

18. Domingues RB, Duarte H, Rocha NP, Teixeira AL. Neurotrophic factors in tension-type headache. Arq Neuropsiquiatr. 2015;73(5):420-4. doi:10.1590/0004-282X20150000

19. The International Classification of Headache Disorders: 2 nd edition. Cephalalgia. 2004;24(1 Suppl):9-160.

20. Kosinski M, Bayliss MS, Bjorner JB, Ware JE Jr, Garber WH, Batenhorst A et al. A six-item short-form survey for measuring headache impact: the HIT-6. Qual Life Res. 2003;12(8):963-74. doi:10.1023/A:1026119331193

21. Lipton RB, Bigal ME, Ashina S, Burstein R, Silberstein S, Reed ML et al. Cutaneous allodynia in the migraine population. Ann Neurol. 2008;63(2):148-58. 10.1002/ana.21211

22. Ochi-ishi R, Nagata K, Inoue T, Tozaki-Saitoh H, Tsuda M, Inoue K. Involvement of the chemokine CCL3 and the purinoceptor P2X7 in the spinal cord in paclitaxel-induced mechanical allodynia. Mol Pain. 2014;10(1):53. doi:10.1186/1744-8069-10-53

23. Freitag CM, Miller RJ. Peroxisome proliferator-activated receptor agonists modulate neuropathic pain: a link to chemokines? Front Cell Neurosci. 2014;8:238. doi:10.3389/fncel.2014.00238

24. Fidan I, Yüksel S, Ymir T, Irkeç C, Aksakal FN. The importance of cytokines, chemokines and nitric oxide in pathophysiology of migraine. J Neuroimmunol. 2006;171(1-2):184-8. doi:10.1016/j.jneuroim.2005.10.005 
25. Noseda R, Burstein R. Migraine pathophysiology: anatomy of the trigemino vascular pathway and associated neurological symptoms, CSD, sensitization and modulation of pain. Pain. 2013;154 Suppl 1. doi:10.1016/j.pain.2013.07.021

26. Lippi G, Meschi T, Mattiuzzi C, Borghi L, Targher G. Adiponectin and migraine: systematic review of clinical evidence. Neurol Sci. 2014;35(8):1167-71. doi:10.1007/s10072-014-1719-3

27. Dodick D, Silberstein S. Central sensitization theory of migraine: clinical implications. Headache. 2006;46(Suppl s4):S182-91. doi:10.1111/j.1526-4610.2006.00602.x
28. Barbosa IG, Rocha NP, Bauer ME, Miranda AS, Huguet RB, Reis HJ. Chemokines in bipolar disorder: trait or state? Eur Arch Psychiatry Clin Neurosci. 2013;263(2):159-65. doi:10.1007/s00406-012-0327-6

29. Fontenelle LF, Barbosa IG, Luna JV, Sousa LP, Abreu MN, Teixeira AL. A cytokine study of adult patients with obsessivecompulsive disorder. Compr Psychiatry. 2012;53(6):797-804. doi:10.1016/j.comppsych.2011.12.00

30. Barbosa IG, Rocha NP, Miranda AS, Magalhães PV, Huguet RB, Souza LP et al. Increased levels of adipokines in bipolar disorder.J Psychiatr Res. 2012;46(3):389-93. doi:10.1016/j.jpsychires.2011.11.010 